\title{
Atmospheric Loadings of Lead From Refined Petroleum Products Consumption in Southwestern Nigeria
}

\author{
L. A. Jimoda, ${ }^{1}$ S. O. Olatunji, ${ }^{2}$ J. A. Adeniran, ${ }^{1}$ B. S. Fakinle, ${ }^{2}$ and J. A. Sonibare ${ }^{2}$ \\ ${ }^{1}$ Environmental Engineering Research Laboratory, Department of Chemical Engineering, Ladoke \\ Akintola University of Technology, Ogbomoso, Nigeria \\ ${ }^{2}$ Environmental Engineering Research Laboratory, Department of Chemical Engineering, Obafemi \\ Awolowo University, Ile-Ife, Nigeria
}

\begin{abstract}
Deleterious impact of lead from the use of motor fuels is of major concern. Lead levels of gasoline and diesel samples from States in Southwestern Nigeria were analysed by Atomic Absorption Spectrometer, according to the standard ASTM D3237-97 method. Lead concentrations ranged from 0.491-1.903 $\mathrm{mg} / \mathrm{L}$ for gasoline and $2.301-10.97 \mathrm{mg} / \mathrm{L}$ for diesel. Estimated lead levels in gasoline were below the Department of Petroleum Resources (DPR) Nigeria limit of $3.37 \mathrm{mg} / \mathrm{l}$. Percentage lead contributions from gasoline and diesel fuel consumption were minimal due to various fuel lead-level regulations that have been established over the years.
\end{abstract}

Keywords: lead, atomic absorption spectrometer, gasoline, diesel

\section{INTRODUCTION}

Lead $(\mathrm{Pb})$ is added to fuel as a cost-effective way of increasing the octane number and providing a measure of protection from valve seat wear, which occurs when metal to metal contact of the valve and seat faces cause premature wear (Segui, 2005). The presence of trace metals and nonmetals in the crude oil and refined petroleum products is destructive, especially in a refining process (Tijjani et al., 2012). Several toxic metals, including arsenic, cadmium, lead, zinc, antimony, and their compounds, are associated with fine particulate matter in ambient air and are known to be emitted during the combustion of fuel in electric power plants, engine of vehicles, furnaces and fire places (Atiku et al., 2011).

Anthropogenic sources of $\mathrm{Pb}$ account for its most common sources in the environment largely because it has been widely used throughout history and remains persistent in the environment. These sources also are the most prevalent sources of human $\mathrm{Pb}$ exposure, including exposure of the general population and occupational (U.S. Environmental Protection Agency, 1986). A variety of sources and activities contribute to air emissions of $\mathrm{Pb}$, including mobile, area, and stationary sources. In the recent past, the major source of $\mathrm{Pb}$-containing air emissions was the consumption of leaded gasoline in motor vehicles. In 1984 over $89 \%$ of an estimated total of 39,000 tons of $\mathrm{Pb}$ emitted was attributed to gasoline consumption (U.S. Environmental Protection Agency, 1986). Its global amounts of wet and dry deposition have been estimated to be roughly equal. Of an estimated global atmospheric $410 \times 10^{6} \mathrm{~kg} /$ year $\mathrm{Pb}$ deposition, $208 \times 10^{6} \mathrm{~kg} /$ year was attributed to wet deposition and $202 \times 10^{6}$

Address correspondence to S. O. Olatunji, Environmental Engineering Research Laboratory, Department of Chemical Engineering, Obafemi Awolowo University, Ile-Ife, Nigeria. E-mail: olatunjiolatunde@yahoo.com

Color versions of one or more of the figures in the article can be found online at www.tandfonline.com/lpet. 
kg/year to dry deposition (U.S. Environmental Protection Agency, 1986). Their respective annual emissions in Nigeria were 2,790 tons/year (Obioh et al., 1994; Nriagu et al., 1996).

Several methods employed to determine lead levels of refined petroleum products by earlier studies are flame atomic absorption spectrometry (FAAS; Sebor et al., 1982; Osinbanjo et al., 1984; Hammond et al., 1998), electrothermal atomic absorption spectrometry (ET-AAS; Gonzalez et al., 1987; Korn et al., 2007), inductively coupled plasma optical emission spectroscopy (ICP-OES; Borszeki et al., 1992; Brenner et al., 1996; Korn et al., 2007), and inductively coupled plasma mass spectrometry (ICP-MS; Al-Swaidan, 1996; Botto, 2002; Pereira et al., 2010). ICP-MS is highly sensitive multielement technique, but the introduction of organic solvents and the compounds in plasma requires special care similar to ICP-OES, because the organic load may destabilize or extinguish the plasma (Lord, 1991). Other techniques used but not widely reported are aqueous iodine monochloride (Ronald et al., 1967), energy-dispersive X-ray fluorescence spectrometry (Yan et al., 2003), and electroanalytical stripping technique (Munoz et al., 2007).

Over time, as concern over the health effects associated with lead began to grow, health and environmental regulations were enacted to restrict the use of lead in certain products and activities in the world. The new behavioral impairment of children intellectual development is a major concern from lead exposure and can lead to death. The health effects associated with exposure to lead vary widely depending on the level of exposure, the physiological system affected and the receptor (Osuntogun and Koku, 2007). As lead level determination is a primary step for the accurate prediction of lead forming potentials from fuel consumption, the need arises to first determine the present lead level of the refined petroleum products consumed in Southwestern Nigeria to estimate the current contribution of lead air emissions from gasoline and diesel combustion to the national airshed.

\section{EXPERIMENTAL}

\section{Study Area}

The study area is Southwestern Nigeria, which consists of Lagos, Ogun, Oyo, Osun, Ondo, and Ekiti States (represented as L, G, Y, S, N, and E) for easy identification of samples (Table 1). The area (Figure 1) lies between longitude $2^{\circ} 31^{\prime}$ and $6^{\circ} 00^{\prime} \mathrm{E}$ and Latitude $6^{\circ} 21^{\prime}$ and $8^{\circ} 37^{\prime} \mathrm{N}$. It has a combined land area of $76,352 \mathrm{~km}^{2}$.

TABLE 1

Sample Coding

\begin{tabular}{|c|c|c|}
\hline State & Gasoline Sample & Diesel Sample \\
\hline Osun & $\begin{array}{lll}S_{g 1} & S_{g 2} & S_{g}\end{array}$ & $\begin{array}{lll}\mathrm{S}_{\mathrm{d} 1} & \mathrm{~S}_{\mathrm{d} 2} & \mathrm{~S}_{\mathrm{d} 3}\end{array}$ \\
\hline Oуо & $\mathrm{Y}_{\mathrm{g} 1} \quad \mathrm{Y}_{\mathrm{g} 2} \quad \mathrm{Y}_{\mathrm{g} 3}$ & $\begin{array}{lll}Y_{\mathrm{d} 1} & Y_{\mathrm{d} 2} & Y_{\mathrm{d} 3}\end{array}$ \\
\hline Ogun & $\mathrm{G}_{\mathrm{g} 1} \quad \mathrm{G}_{\mathrm{g} 2} \quad \mathrm{G}_{\mathrm{g} 3}$ & $\begin{array}{lll}\mathrm{G}_{\mathrm{d} 1} & \mathrm{G}_{\mathrm{d} 2} & \mathrm{G}_{\mathrm{d} 3}\end{array}$ \\
\hline Lagos & $\begin{array}{lll}\mathrm{L}_{\mathrm{g} 1} & \mathrm{~L}_{\mathrm{g} 2} & \mathrm{~L}_{\mathrm{g} 3}\end{array}$ & $\begin{array}{lll}\mathrm{L}_{\mathrm{d} 1} & \mathrm{~L}_{\mathrm{d} 2} & \mathrm{~L}_{\mathrm{d} 3}\end{array}$ \\
\hline Ekiti & $\begin{array}{lll}E_{\mathrm{g} 1} & E_{\mathrm{g} 2} & \mathrm{E}_{\mathrm{g} 3}\end{array}$ & $\begin{array}{lll}\mathrm{E}_{\mathrm{d} 1} & \mathrm{E}_{\mathrm{d} 2} & \mathrm{E}_{\mathrm{d} 3}\end{array}$ \\
\hline Ondo & $\begin{array}{lll}\mathrm{N}_{\mathrm{g} 1} & \mathrm{~N}_{\mathrm{g} 2} & \mathrm{~N}_{\mathrm{g} 3}\end{array}$ & $\begin{array}{lll}N_{d 1} & N_{d 2} & N_{d} 3\end{array}$ \\
\hline
\end{tabular}

$\mathrm{S}=$ Osun State $; \mathrm{Y}=$ Oyo State $; \mathrm{G}=$ Ogun State; $\mathrm{L}=$ Lagos State; $\mathrm{E}=$ Ekiti State; $\mathrm{N}=$ Ondo State. Gasoline $=\mathrm{g}$; Diesel $=\mathrm{d}$; Position of filling station $=1,2$, or 3 . 


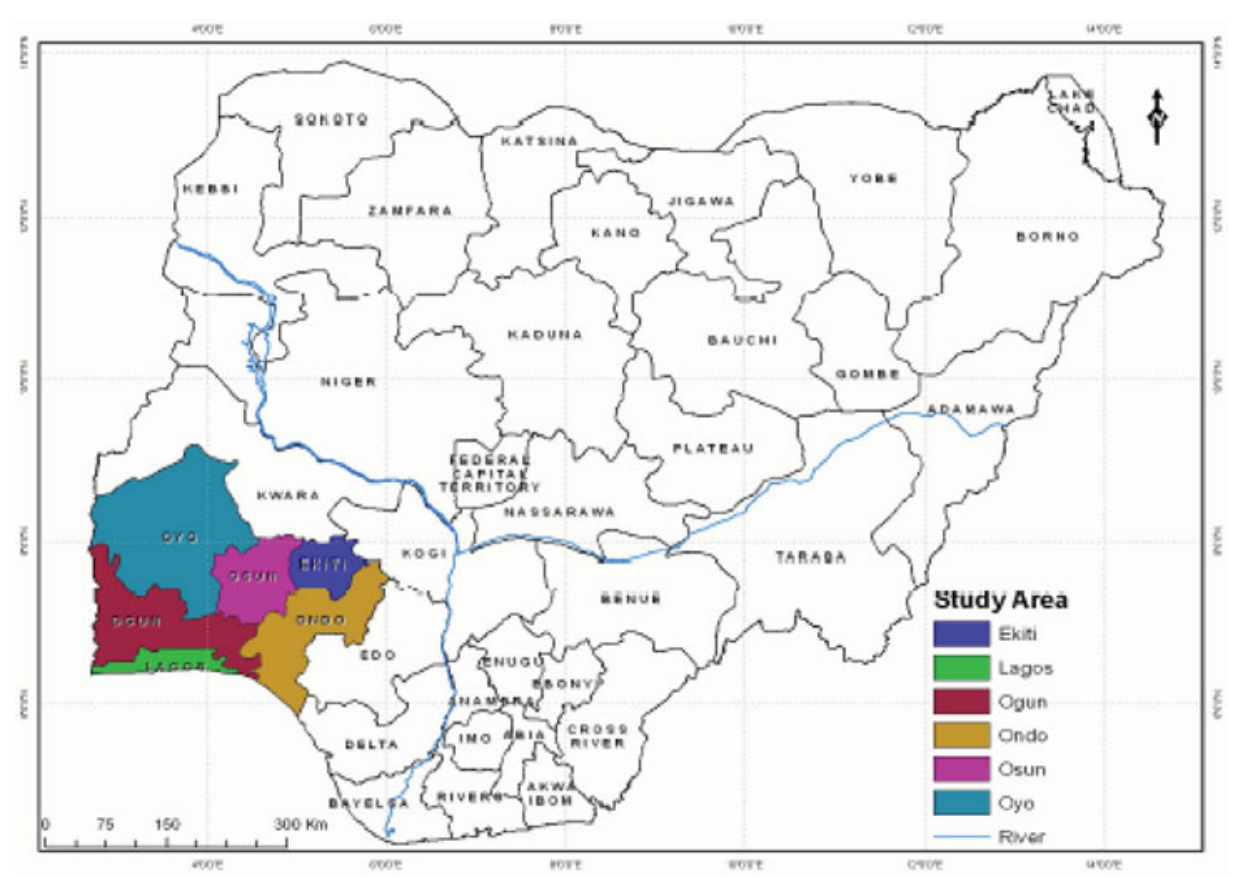

FIGURE 1 The Study Area in Nigeria.

\section{Sample Collection and Storage}

Three different gasoline and diesel fuel samples were collected from each of the six states in southwestern Nigeria into plastic bottles and stored in the laboratory at room temperature before analysis. The lead levels of the collected samples were determined using ASTM D3237-97 standard test method for lead in gasoline and diesel by atomic absorption spectrometry (AAS) at wavelength of $283.3 \mathrm{~nm}$. The lead levels of all the petroleum products analyzed in this study were determined on a Model PG-900 atomic absorption spectrometer.

Glassware was deleaded by rinsing with dilute nitric acid $(1+1)$ and then rinsed with distilled water. Glassware was also washed with acetone and dried at $50 \pm 5^{\circ} \mathrm{C}$. The average density of all the gasoline samples collected for this study is $0.739 \mathrm{~kg} / \mathrm{L}$ while the average density of all the diesel samples collected is $0.844 \mathrm{~kg} / \mathrm{L}$. In the preparation of the working standards for lead analysis, five different concentrations $(0.0,0.25,0.50,0.75$, and $2.00 \mathrm{ppm})$ of lead solution were prepared from the standard stock lead solution (1000 ppm).

In preparing blank for lead in gasoline and diesel analysis, $30 \mathrm{~mL}$ of MIBK were added to $10 \mathrm{~mL}$ of iso-octane in a $250 \mathrm{~mL}$ volumetric flask. A drop of iodine solution was added to the flask and the solution was mixed thoroughly and allowed to react for at $1 \mathrm{~min}$. Also, $5 \mathrm{~mL}$ of $1 \%$ Aliquat/MIBK solution was added and mixed. The solution in the flask was diluted to $50 \mathrm{~mL}$ mark of the flask with MIBK and thoroughly mixed.

\section{Preparation of Gasoline and Diesel Samples for Analysis}

In preparing gasoline and diesel samples for analysis, $30 \mathrm{~mL}$ of MIBK, $10 \mathrm{~mL}$ of gasoline sample, a drop of iodine solution, and $5 \mathrm{~mL}$ of iso-octane were added to a $250 \mathrm{~mL}$ volumetric flask. The 
solution in the flask was mixed thoroughly and reaction was allowed to take place for 3 min before $5 \mathrm{~mL}$ of $1 \%$ Aliquat/MIBK solution was added.

\section{Standardization and Analysis}

The reagent blank was aspirated and the instrument was adjusted to zero. Absorbances of the 0.25 , $0.50,0.75$, and $2.00 \mathrm{ppm}$ lead working standards were measured. Gasoline/diesel samples were then aspirated and the absorbance values were recorded. The blank was aspirated between each sample measurement. The instrument automatically prepared a calibration curve by plotting the absorbance of the working standards against their concentrations ( $\mathrm{ppm}$ ) on linear graph. The AAS measured the absorbance of each fuel sample three times and automatically calculated the average absorbance, standard deviation and percentage relative standard deviation. A second order curve equation that relates the concentration of lead in the sample to the absorbance of lead in the sample was also generated by the instrument. The concentration of lead in gasoline and diesel was estimated by manually substituting the absorbance of each fuel sample into the curve equation generated by AAS.

\section{Estimation of Lead Emission}

The annual $\mathrm{Pb}$ emission from consumption of refined petroleum products was estimated using a combination of annual domestic consumption of refined petroleum products data from Nigerian National Petroleum Corporation annual statistical bulletin (Table 2) and mass balance approach.

TABLE 2

Refined Petroleum Products Consumption in Southwestern Nigeria in Selected Years

\begin{tabular}{|c|c|c|c|c|c|c|}
\hline Year & Ekiti & Lagos & Ogun & Ondo & Osun & Oyo \\
\hline \multicolumn{7}{|c|}{ Gasoline, L } \\
\hline 1997 & $2,632,000$ & $952,777,000$ & $189,458,000$ & $74,605,000$ & $57,734,000$ & $181,522,000$ \\
\hline 1998 & $8,291,000$ & $1,175,334,000$ & $232,020,000$ & $50,123,000$ & $48,582,000$ & $152,499,000$ \\
\hline 1999 & $10,887,000$ & $1,259,751,000$ & $178,944,000$ & $65,348,000$ & $68,573,000$ & $187,742,000$ \\
\hline 2000 & $9,342,000$ & $888,348,000$ & $169,110,000$ & $50,242,000$ & $51,309,000$ & $166,312,000$ \\
\hline 2001 & $14,915,000$ & $1,491,505,000$ & $302,288,000$ & $91,744,000$ & $93,730,000$ & $277,571,000$ \\
\hline 2002 & $25,188,000$ & $1,361,908,000$ & $247,861,000$ & $119,932,000$ & $113,015,000$ & $267,124,000$ \\
\hline 2005 & $37,641,000$ & $1,499,452,000$ & $276,292,000$ & $110,478,000$ & $88,248,000$ & $318,263,000$ \\
\hline 2009 & $54,356,220$ & $1,449,075,060$ & $286,286,550$ & $106,205,310$ & $124,943,170$ & $340,031,080$ \\
\hline 2010 & $32,728,660$ & $635,350,860$ & $140,925,810$ & $77,616,510$ & $100,764,910$ & $183,031,080$ \\
\hline 2011 & $32,870,380$ & $486,591,090$ & $82,322,750$ & $72,166,760$ & $52,643,360$ & $150,086,430$ \\
\hline \multicolumn{7}{|c|}{ Diesel, L } \\
\hline 1997 & 520,000 & $324,633,000$ & $40,371,000$ & $22,335,000$ & $9,917,000$ & $66,417,000$ \\
\hline 1998 & $1,267,000$ & $300,242,000$ & $32,531,000$ & $12,630,000$ & $5,969,000$ & $44,653,000$ \\
\hline 1999 & $1,021,000$ & $382,102,000$ & $40,600,000$ & $12,919,000$ & $10,582,000$ & $49,287,000$ \\
\hline 2000 & 755,000 & $336,428,000$ & $47,663,000$ & $6,960,000$ & $6,960,000$ & $53,418,000$ \\
\hline 2001 & $2,835,000$ & $360,493,000$ & $54,286,000$ & $28,098,000$ & $22,327,000$ & $70,009,000$ \\
\hline 2002 & $2,835,000$ & $264,609,000$ & $38,076,000$ & $14,644,000$ & $15,509,000$ & $48,813,000$ \\
\hline 2005 & $2,081,000$ & $302,351,000$ & $31,959,000$ & $15,110,000$ & $5,518,000$ & $39,805,000$ \\
\hline 2009 & $2,208,300$ & $129,987,960$ & $40,612,760$ & $4,263,390$ & $3,550,940$ & $25,646,320$ \\
\hline 2010 & $1,373,870$ & $66,185,208$ & $8,438,990$ & $3,375,580$ & $3,939,840$ & $13,875,670$ \\
\hline 2011 & $2,980,230$ & $41,397,670$ & $7,379,350$ & $4,587,760$ & $4,794,440$ & $9,284,600$ \\
\hline
\end{tabular}

Source: Nigerian National Petroleum Corporation (2011). 
Mass balance was the preferred methodology for estimating uncontrolled emissions of $\mathrm{Pb}$ from fuel combustion in this study. A worst case scenario proposed by the U.S. Environmental Protection Agency (1986) that suggested that because oil combustion does not generate any bottom ash, it can generally be assumed that $100 \%$ of the trace elements present in the fuel are released into the atmosphere upon combustion was adopted in this study. It was generally assumed in this study that the lead content of the fuel was constant for the 10 selected years. The annual lead emissions from gasoline and diesel consumption were calculated using Eq. (1).

$$
\begin{aligned}
\text { Annual Emission Rate }= & \text { Annual Fuel Consumption }(L / y r) \\
& * \text { Lead Content of Fuel }(m g / L)
\end{aligned}
$$

The total annual emission of lead in the Southwestern Nigeria was calculated by summing the annual average lead emissions from all the six Southwestern states of Nigeria.

\section{RESULTS AND DISCUSSION}

A standard calibration curve (Figure 2) was generated from standard solution prepared. Statistical analysis showed that the fit gave a good measure of regression with dependency value of 0.9983 . The validity of the calibration curve was verified with the closeness of this dependency value to unity. This observation is in consonance with past reports on calibration plot. A second-order Eq. (2) and constants $K_{0}, K_{1}$, and $K_{2}$ were generated directly from AAS. This was used to estimate lead concentrations presented in Table 3 by substituting the absorbances of the petroleum product samples.

$$
[C]=k_{2} *[A]^{2}+k_{1} *[A]+k_{0}
$$

Equation factor: $\mathrm{K}_{2}=1521.4385, \mathrm{~K}_{1}=80.2213, \mathrm{~K}_{0}=-0.0750$, and dependency $=0.99831$.

As shown in Table 3, the $\mathrm{Pb}$ concentrations of the gasoline fuel samples analyzed ranged from $0.491-0.903 \mathrm{mg} / \mathrm{L}$. The maximum observed $\mathrm{Pb}$ concentration of $1.903 \mathrm{mg} / \mathrm{L}$ was obtained in the $\mathrm{L}_{\mathrm{g} 3}$ gasoline sample from Lagos State while minimum measured $\mathrm{Pb}$ concentration of $0.491 \mathrm{mg} / \mathrm{L}$ was obtained in the $\mathrm{Y}_{\mathrm{g} 1}$ gasoline sample from Oyo State. However, all the collected gasoline samples from the investigated region analyzed for $\mathrm{Pb}$ contained $\mathrm{Pb}$ levels below the specified limit of $5 \mathrm{ppm}$ recommended by the DPR.

The results of $\mathrm{Pb}$ concentrations in the diesel fuel samples obtained from each of the six states in Southwestern Nigeria are presented in Table 3. The concentrations ranged between 2.30 and

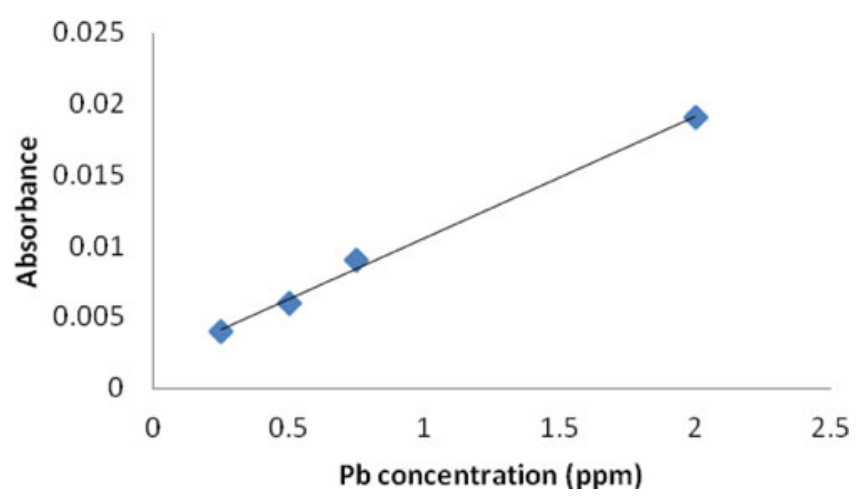

FIGURE 2 Calibration plot for lead in gasoline and diesel fuel. 
TABLE 3

Absorbance and Concentration of Lead $(\mathrm{Pb})$ in the Investigated Fuel Samples

\begin{tabular}{|c|c|c|c|c|c|}
\hline Sample & Average Absorbance & Concentration, ppm & Concentration, $\mathrm{mg} / \mathrm{L}$ & $S D$ & $\% R S D$ \\
\hline \multicolumn{6}{|c|}{ Gasoline } \\
\hline $\mathrm{S}_{\mathrm{g} 1}$ & 0.015 & 1.471 & 1.087 & 0.0024 & 2.584 \\
\hline $\mathrm{S}_{\mathrm{g} 2}$ & 0.015 & 1.471 & 1.087 & 0.0024 & 2.593 \\
\hline $\mathrm{S}_{\mathrm{g} 3}$ & 0.010 & 0.879 & 0.650 & 0.0023 & 2.632 \\
\hline $\mathrm{Y}_{\mathrm{g} 1}$ & 0.008 & 0.664 & 0.491 & 0.0035 & 4.041 \\
\hline $\mathrm{Y}_{\mathrm{g} 2}$ & 0.015 & 1.471 & 1.087 & 0.0031 & 3.318 \\
\hline $\mathrm{Y}_{\mathrm{g} 3}$ & 0.018 & 1.862 & 1.376 & 0.0004 & 0.401 \\
\hline $\mathrm{G}_{\mathrm{g} 1}$ & 0.013 & 1.225 & 0.905 & 0.0024 & 2.644 \\
\hline $\mathrm{G}_{\mathrm{g} 2}$ & 0.018 & 1.862 & 1.376 & 0.0036 & 3.745 \\
\hline $\mathrm{G}_{\mathrm{g} 3}$ & 0.015 & 1.471 & 1.807 & 0.0024 & 2.571 \\
\hline $\mathrm{L}_{\mathrm{g} 1}$ & 0.021 & 2.281 & 1.685 & 0.0012 & 1.247 \\
\hline $\mathrm{L}_{\mathrm{g} 2}$ & 0.019 & 1.998 & 1.477 & 0.0035 & 3.508 \\
\hline $\mathrm{L}_{\mathrm{g} 3}$ & 0.023 & 2.575 & 1.903 & 0.0054 & 5.271 \\
\hline $\mathrm{E}_{\mathrm{g} 1}$ & 0.022 & 2.426 & 1.793 & 0.0011 & 1.132 \\
\hline $\mathrm{E}_{\mathrm{g} 2}$ & 0.016 & 1.598 & 1.181 & 0.0024 & 2.560 \\
\hline $\mathrm{E}_{\mathrm{g} 3}$ & 0.020 & 2.138 & 1.580 & 0.0022 & 2.268 \\
\hline $\mathrm{N}_{\mathrm{g} 1}$ & 0.020 & 2.138 & 1.580 & 0.0009 & 0.951 \\
\hline $\mathrm{N}_{\mathrm{g} 2}$ & 0.020 & 2.138 & 1.580 & 0.0044 & 4.487 \\
\hline $\mathrm{N}_{\mathrm{g} 3}$ & 0.021 & 2.281 & 1.685 & 0.0012 & 1.167 \\
\hline \multicolumn{6}{|c|}{ Diesel } \\
\hline $\mathrm{S}_{\mathrm{d} 1}$ & 0.051 & 7.974 & 6.730 & 0.0015 & 1.322 \\
\hline $\mathrm{S}_{\mathrm{d} 2}$ & 0.054 & 8.693 & 7.337 & 0.0007 & 0.636 \\
\hline $\mathrm{S}_{\mathrm{d} 3}$ & 0.039 & 5.368 & 4.530 & 0.0071 & 6.962 \\
\hline $\mathrm{Y}_{\mathrm{d} 1}$ & 0.070 & 12.99 & 10.97 & 0.0017 & 1.309 \\
\hline $\mathrm{Y}_{\mathrm{d} 2}$ & 0.024 & 2.727 & 2.301 & 0.0018 & 2.019 \\
\hline $\mathrm{Y}_{\mathrm{d} 3}$ & 0.043 & 6.188 & 5.222 & 0.0045 & 4.198 \\
\hline $\mathrm{G}_{\mathrm{d} 1}$ & 0.043 & 6.188 & 5.222 & 0.0019 & 1.783 \\
\hline $\mathrm{G}_{\mathrm{d} 2}$ & 0.042 & 5.978 & 5.046 & 0.0026 & 2.448 \\
\hline $\mathrm{G}_{\mathrm{d} 3}$ & 0.061 & 10.48 & 8.845 & 0.0011 & 0.926 \\
\hline $\mathrm{L}_{\mathrm{d} 1}$ & 0.045 & 6.616 & 5.584 & 0.0025 & 2.279 \\
\hline $\mathrm{L}_{\mathrm{d} 2}$ & 0.058 & 9.696 & 8.183 & 0.0043 & 3.558 \\
\hline $\mathrm{L}_{\mathrm{d} 3}$ & 0.037 & 4.976 & 4.200 & 0.0029 & 2.884 \\
\hline $\mathrm{E}_{\mathrm{d} 1}$ & 0.060 & 10.22 & 8.622 & 0.0022 & 1.774 \\
\hline $\mathrm{E}_{\mathrm{d} 2}$ & 0.037 & 4.976 & 4.200 & 0.0036 & 3.590 \\
\hline $\mathrm{E}_{\mathrm{d} 3}$ & 0.038 & 5.170 & 4.364 & 0.0031 & 3.027 \\
\hline $\mathrm{N}_{\mathrm{d} 1}$ & 0.066 & 11.85 & 9.999 & 0.0027 & 2.083 \\
\hline $\mathrm{N}_{\mathrm{d} 2}$ & 0.047 & 7.056 & 5.955 & 0.0017 & 1.536 \\
\hline $\mathrm{N}_{\mathrm{d} 3}$ & 0.051 & 7.974 & 6.730 & 0.0015 & 1.286 \\
\hline
\end{tabular}

$\% \mathrm{RSD}=$ percentage relative standard deviation.

$10.97 \mathrm{mg} / \mathrm{L}$. The minimum obtained $\mathrm{Pb}$ concentration of $2.30 \mathrm{mg} / \mathrm{L}$ was obtained in the $\mathrm{Y}_{\mathrm{d} 1}$ diesel sample from Oyo State while the maximum measured $\mathrm{Pb}$ concentration of $10.97 \mathrm{mg} / \mathrm{L}$ was obtained in the $\mathrm{Y}_{\mathrm{d} 2}$ diesel sample from Oyo State.

The pronounced variations in the $\mathrm{Pb}$ concentrations of gasoline and diesel samples could be due to the importations of refined petroleum products of non-uniform quality in Nigeria, storage of petroleum products from various sources over a long period of time, fuel adulteration and use of contaminated tankers. The minimal or negligible deviation of the measured $\mathrm{Pb}$ concentrations from standard suggests AAS as an excellent instrumentation method for accurate determination of 


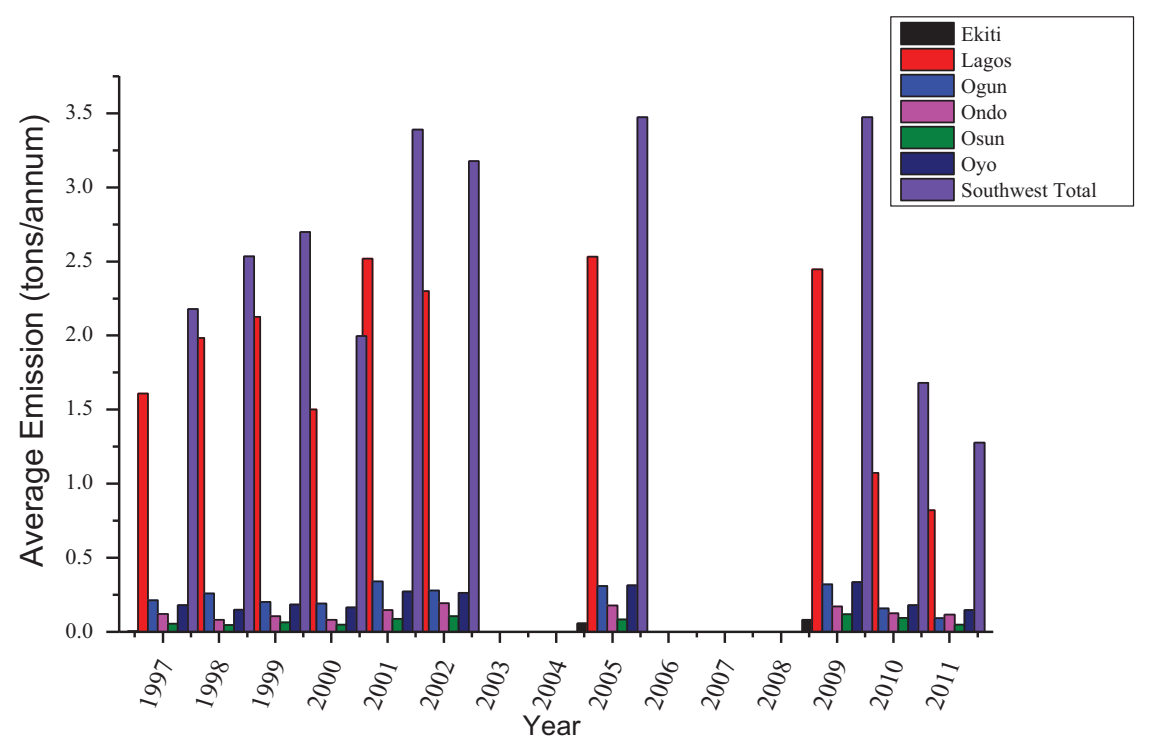

(a) Emissions from Gasoline

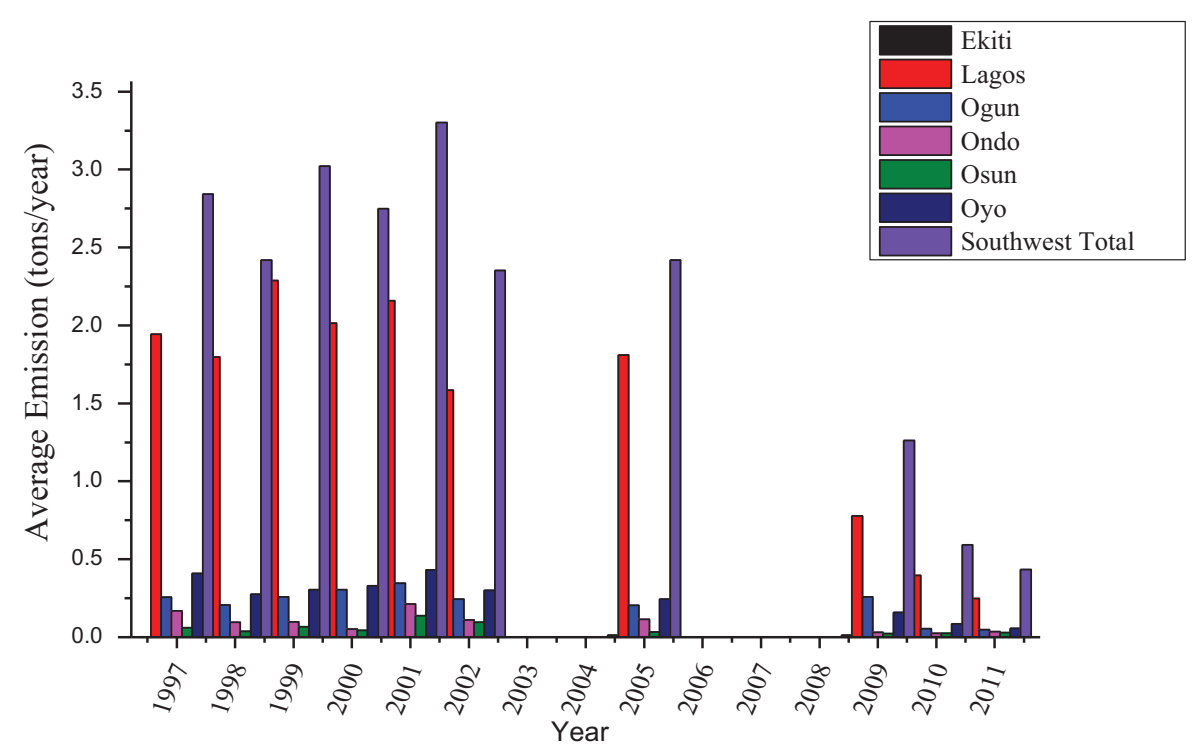

(b) Emissions from Diesel

FIGURE 3 Total annual emission of lead from diesel and gasoline consumption in Southwestern Nigeria.

lead in gasoline and diesel fuels. The highest $\mathrm{Pb}$ emission of 3.47 tons/year was obtained in 2009, while the lowest $\mathrm{Pb}$ emission of 1.28 tons/year was recorded in 2011 (Figure 3). In comparison with the estimated annual total atmospheric lead emissions of 2,790 tons/year in Nigeria reported by Obioh et al. (1994), the result of the percentage contribution of annual $\mathrm{Pb}$ emission from gasoline 
consumption in Southwestern Nigeria to the annual national $\mathrm{Pb}$ emission level shows $0.078 \%$ in $1997,0.091 \%$ in $1998,0.096 \%$ in $1999,0.071 \%$ in $2000,0.121 \%$ in $2001,0.114 \%$ in $2002,0.124 \%$ in $2005,0.124 \%$ in $2009,0.060 \%$ in 2010 , and $0.046 \%$ in 2011.

The result of the annual percentage contribution of $\mathrm{Pb}$ emission from diesel consumption in Southwestern Nigeria to the annual national $\mathrm{Pb}$ emission level indicates $0.078 \%$ in $1997,0.091 \%$ in $1998,0.096 \%$ in $1999,0.071 \%$ in $2000,0.121 \%$ in $2001,0.114 \%$ in $2002,0.124 \%$ in $2005,0.124 \%$ in $2009,0.060 \%$ in 2010 , and $0.046 \%$ in 2011 using the estimated annual total atmospheric lead emissions of 2,790 tons/year in Nigeria reported by Obioh et al (1994) as the standard national $\mathrm{Pb}$ emission level. Figure 3 shows that the lowest $\mathrm{Pb}$ emission of 0.434 ton/year was recorded in 2011 while the highest $\mathrm{Pb}$ emission of 3.302 tons/year was obtained in 2001. The percentage contribution of lead emission from fuel consumption estimated in this study to national lead emissions level is very low because of the various fuel lead level regulations that have been established over the years to phase out the consumption of leaded fuel. It is therefore expected that the current national lead emissions level would have dropped drastically compared to the levels reported by Obioh et al. (1994) and Nriagu et al. (1996).

\section{CONCLUSIONS}

In this study, atmospheric loadings of lead from gasoline and diesel consumption in Southwestern Nigeria for 10 selected years were investigated. Laboratory experiments were carried out to determine the lead levels of in gasoline and diesel consumed in the part of the country. The petroleum product samples analyzed contained a wide variety of lead concentrations ranging from $0.491-1.903 \mathrm{mg} / \mathrm{L}$ for gasoline and 2.301-10.97 mg/L for diesel. The obtained results showed total level of compliance of the lead level in all the gasoline samples from Southwestern Nigeria with the lead limit of $3.37 \mathrm{mg} / \mathrm{L}$ ( $5 \mathrm{ppm}$ ) recommended by the Department of Petroleum Resources (DPR) Nigeria. However, no lead limit was specified by DPR for the lead level of diesel fuel.

The percentage contributions of lead emissions to the national annual lead emissions level were found to be very minimal. The study suggested that to mitigate the air emissions of lead, a cleaner technology control approach should be adopted in the form of fuel modification. As lead emission is proportional to the lead contents of the fuel, the use of unleaded fuel must be enforced. It also, suggested that future work should be extended to investigate the contribution of lead emissions from consumption of refined petroleum products in other zones and Federal Capital Territory of Nigeria to the national emission levels. The results of this study will further help to identify appropriate control technology for the mitigation of air emissions of lead from refined petroleum products in the country.

\section{REFERENCES}

Al-Swaidan, H. M. (1996). The determination of lead, nickel and vanadium in Saudi Arabian crude oil by sequential injection analysis inductively coupled plasma mass spectrometry. Talanta 43:1313-1319.

Atiku, F. A., Ikeh, P. O., Faruk, U. Z., Itodo, A. U., Abdulhamid, A., and Rikoto, I. I. (2011). Comparative test analysis of petroleum (diesel and gasoline) soots as potential sources of toxic metals from exhausts of power plants. Scholars Research Library, Arch. Appl. Sci. Res. 3:147-156.

Borszeki, J., Knapp, G., Halmos, P., and Bartha, L. (1992). Sample preparation procedure for the determination of sulphur and trace metals in oil products by the ICP with a minitorch using emulsions. Microchim. Acta 108:157-161.

Botto, R. I. (2002). Trace element analysis of petroleum naphthas and tars using direct injection ICP-MS. Can. J. Anal. Sci. Spectrosc. 47:1-13.

Brenner, I. B., Zander, A., Kim, S., and Shkolnik, J. (1996). Direct determination of lead in gasoline using emulsification and argon-oxygen inductively coupled plasma atomic emission spectrometry. J. Anal. Atom. Spectrom. 11:91-97. 
Gonzalez, M. C., Rodriguez, A. R., and Gonzalez. V. (1987). Determination of vanadium, nickel, iron, copper, and lead in petroleum fraction by atomic absorption spectrophotometry with a graphite furnace. Mirochem. J. 57:94-106.

Hammond, J. L., Lee, Y., Noble, C. O., Beck, J. N., Proffitt, C. E., and Sneddon, J. (1998). Determination of cadmium, lead and nickel by simultaneous multi element flame atomic absorption spectrometry in burned and unburned Venezuelan crude oils. Talanta 47:261-66.

Korn, M. D. G. A., dos Santos, D. S. S., Welz, B., Vale, M. G. R., Teixeira, A. P., de Castro Lima, D., and Ferreira, S. L. C. (2007). Atomic spectrometric methods for the determination of metals in automotive fuels: A review. Talanta 73:1-11.

Lord, C. J. (1991). Determination of trace metals in crude oil by inductively coupled plasma mass spectrometry with micro-emulsion sample introduction. Anal. Chem. J. 63:1594-1599.

Munoz, P. A. A., Correia, P. R. M., Nascimento, A. N., Silva, C. S., Oliveira, P. V., and Angnes, L. (2007). Electro analysis of crude oil and petroleum based fuel for trace metals: Evaluation of different micro-wave assisted sample decompositions and stripping techniques. Energy Fuels 21:295-302.

Nigerian National Petroleum Corporation. (2011). Annual reports Abuja, Nigeria: NNPC.

Nriagu, J. O., Blankson, M. L., and Ocran, K. (1996). Childhood lead poisoning in Africa: A growing public health problem. Sci. Total Environ. 181:93-100.

Obioh, I. B., Oluwole, A. F., Akeredolu, F. A., and Asubiojo, O. I. (1994). National Inventory of Air Pollutants in Nigeria Emissions for 1988. Benin: Ilupeju Press.

Osibanjo, O., Kakulu, S. E., and Ajayi, S. Q. (1984). Analytical application of inorganic salt standards and mixed-solvent systems to trace-metal determination in petroleum crudes by atomic absorption spectrophotometry. Analyst 109:109-127.

Osuntogun, B. A., and Koku, C. A. (2007). Environmental impacts of urban road transportation in South-Western states of Nigeria. J. Appl. Sci. 7:2356-2360.

Pereiria, J. S. F., Moraes, D. P., Antes, F. G., Dieht, L. D., Santos, F. P., Guimaraes, R. C. L., Fonseca, T. C. O., Dressler, V. L., and Flores, E. M. M. (2010). Determination of metals and metalloids in light and heavy crude oil by ICP-MS after digestion by microwave induced combustion. Microchem. J. 96:4-11.

Ronald, M., Campbell, K., and Griffiths, S. T. (1969). Extraction of lead from petroleum products employing aqueous iodine monochloride. U.S. Patent No. 3,481,866.

Sebor, G., Long, I., Kolihova, D., and Wasser, O. (1982). Effect of the type of organometallic iron and copper compounds on the determination of both metals in petroleum by flame atomic absorption spectroscopy. Analyst 107:1350-1355.

Segui, C. (2005). Cleaner Fuel Initiative: Air Quality Enviro-Note by Department of Environmental Protection and the Government of Western Australia, pp. 1-4.

Tijjani, N., Ike, P. O., Usman, B. B., Malami, D. I., and Alaere, M. (2012). Trace elemental analysis of Nigerian petroleum products using AAS method. Int. J. Sci. Eng. Res. 3:1-5.

U.S. Environmental Protection Agency. (1986). Environmental Criteria and Assessment Office: Air quality criteria for lead. EPA/600/8-83-028 aF-dF (Vol. 1-IV). Research Triangle Park, NC: U.S. Environmental Protection Agency.

U.S. Environmental Protection Agency. (2001). Integrated risk information system (IRIS): Lead and compounds (inorganic). CASRN 7439-92-1. Retrieved from http://www.epa.gov/iris/subst/0277.htm

Yan, Z., Hou, X., and Jones, B. T. (2003). Determination of wear metals in engine oil by mild acid digestion and energy dispersive X-ray fluorescence spectrometry using solid phase extraction disks. Talanta 59:673-680. 
Copyright of Petroleum Science \& Technology is the property of Taylor \& Francis Ltd and its content may not be copied or emailed to multiple sites or posted to a listserv without the copyright holder's express written permission. However, users may print, download, or email articles for individual use. 